\title{
Neural Network Modeling and Experimental Evaluation of Organic Solar Panel Performance in Algerian Sahara
}

\author{
Touhami Ghaitaoui $^{1 *}$, Ali Benatiallah ${ }^{2}$, Hamid Khachab ${ }^{3}$, Youcef Sahli ${ }^{1}$, Khaled Koussa ${ }^{1}$ \\ ${ }^{1}$ Unité de Recherche en Energies Renouvelables en Milieu Saharien, URERMS, Centre de Développement des \\ Energies Renouvelables, CDER, 01000, Adrar, Algéria \\ ${ }^{2}$ Department of Technology, Faculty of Science and Technology, University Ahmed Draia, Adrar, Algeria \\ ${ }^{3}$ Faculty of Electrical Engineering, University, Tahri Mohamed, Bechar, Bp 417, Algeria
}

Corresponding Author Email: touhami.eln@gmail.com

https://doi.org/10.18280/ejee.210206

Received: 18 January 2019

Accepted: 9 March 2019

\section{Keywords:}

organic solar cells, artificial neural network, electrical parameters, voltagecurrent characteristic, $P V$ panel

\begin{abstract}
In this paper, the characterization and modeling results of the electrical parameters of the tendem organic photovoltaic cells (infinityPV) are presented. The electrical performances of this organic cell's module (I-V and P-V) are characterized and analyzed in the weather condition of southwest Algeria (Adrar site). A program in MATLAB language is developed locally for modeling the organic cell, using artificial intelligence. The multilayer feed forward perception type ANN is used for extraction of the organic photovoltaic model performances, and the back-propagation algorithm is used for the program training. The ANN obtained results by the simulation showed a good conformity with the results obtained experimentally in the saharan climate (MAPE:0.68\%, MBE:4.5018e-09 A and RMSE:1.8062e-04 A).
\end{abstract}

\section{INTRODUCTION}

Solar photovoltaic cells have experienced rapid development because they represent a key field in the cleaner electrical energy production. Those who grapple with solar photovoltaic science and technology devoted themselves to the study of novel materials and fabrication methods and device configurations for the next generation of solar cells, which must be efficient, low cost, lightweight and flexible [1].

Moreover, for the newly developed technology, namely the organic solar cells of last generation, it has important significance because they have very interesting properties and many advantages [1-2], including the cell flexibility and the ability to be exploited in large areas, the low costs of materials and organic cells fabrication [3-4]. However, the improvement of efficiency and stability must be considerably compared to their current state. But it is very difficult to obtain an matimatical model starting from a priori assumptions, due to the complex nature of the material of OPV itself [1]. On the contrary, an independent model technique is paramount to automatically extract model parameters for the electrical characteristics of this new kinds of photovoltaic cells.

In the photovoltaic field, the manufacturers provide the electical parameters for modules in conditions STC. However, these conditions are not always obvious, occurring seldom outside, because they are mainly carried out under conditions of the laboratory by using a solar simulator matirials. Consequently, to carry out a characterization appropriate to the behavior of electric modules regular minutes (obtaining curves $\mathrm{I}-\mathrm{V}$ and $\mathrm{P}-\mathrm{V}$ ), recently, several authors [5-6] are used the artificial intelligence technics such as the fuzzy logic [5-7] and the artificial neuron networks (ANN) [2, 6-13] to modeling OPV cells. This approach is logical if one were to consider the dependence of the solar cell to any variations conditions of the environment [8]. Galphade [14] has presented a review paper of the photovoltaic module characterizations that using artificial neural networks (ANN). Celik [15] has presented a mode of mono-crystalline photovoltaic modules that based on artificial neural network methods. An artificial neural network based-model (ANN) have introduced by Mekki et al. [16], to detect the partial shading losses in the photovoltaic (PV) panel. Gotleyb [17] have proposed an ANN model for new generation organic solar cells to extract the electrical parameters of the studied organic photovoltaic modules. Riede et al. [18] have presented an optimization of organic (small molecules) tandem solar cells.

In this article, the electrical parameters of flexible tandem OPV module (current-voltage and current-power) are characterized and analyzed in the desert weather condition in the southwest Algeria (Adrar city). In addition, OPV module modeling is approache by using a numerical method basing on an electrical representation of the OPV solar cell. The obtained results by the ANN simulation methods showed a good conformity with the results obtained experimentally.

\section{EXPERIMENTATION}

The experiments are realized in the southwest of Algeria in Adrar city. This region of the Algerian Sahara has one of the greatest solar deposits in the world. The number of sunshine hours amounts almost 3500 hours/year [19]. The mean annual of the daily global irradiance measured on the tilted surface exceeds the value of $7 \mathrm{kWh} / \mathrm{m} . \mathrm{sq} /$ day [20]. The curves presented in Figure 1 give some examples of the GHI, DNI and DHI (data source: New Energy Algeria meteorological station URER-MS Adrar, Algeria). However, this Saharan 
region is characterized by important differences in the temperature over the year. In summer, the daily average of ambient temperature exceeds $42{ }^{\circ} \mathrm{C}$ (the maximum almost reaches $50^{\circ}$ ) while in winter the daily average is around $7{ }^{\circ} \mathrm{C}$ (the minimum is nearly $0{ }^{\circ} \mathrm{C}$ ) Figure 2 . The annual average measured relative humidity in the year 2017 is near $35 \%$.

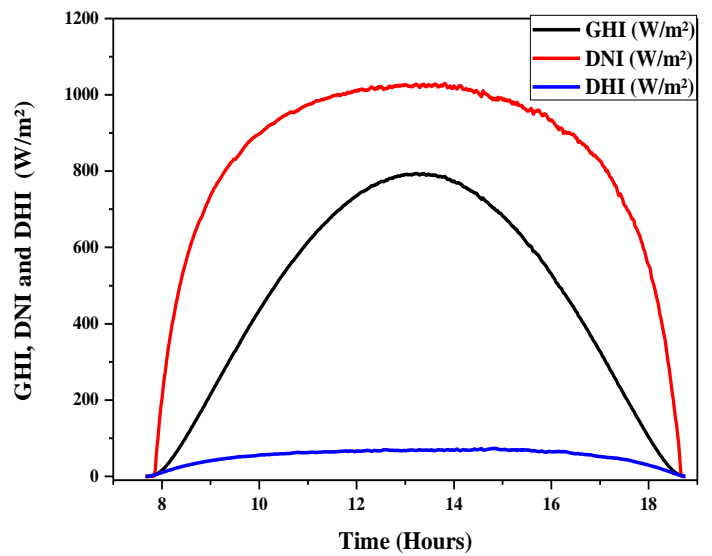

Figure 1. GHI, DNI and DHI variations. Day: 10/01/2017

To testing OPV module performance, we useing the experimental platform installed in URERMS field consists of a computer station, MP-160 I-V tracer (figure 3a), irradiance and temperature sensors and photovoltaic modules consist eight flexible organic tandem solar cells connected in series figure $3 \mathrm{~b}$.

The electrical specifications of the OPV module used in this study are summarized in Table 1 .

In figure $4 \mathrm{a}$, sample curve is extracted experimentally in STC condition $\left(\mathrm{G}=1000 \mathrm{~W} / \mathrm{m} 2\right.$ and $\left.\mathrm{T}=25^{\circ} \mathrm{C}\right)$ by MP-160 $\mathrm{I}-\mathrm{V}$ tracer.
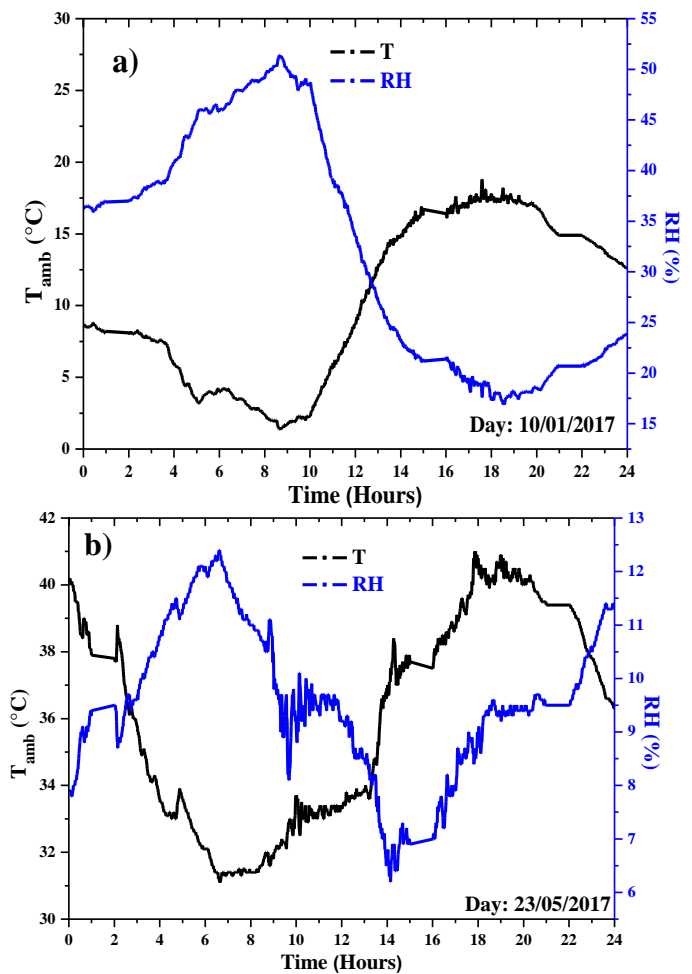

Figure 2. The humidity values and ambient temperature. a) Day: 23/05/2017, b) Day: 10/01/2017

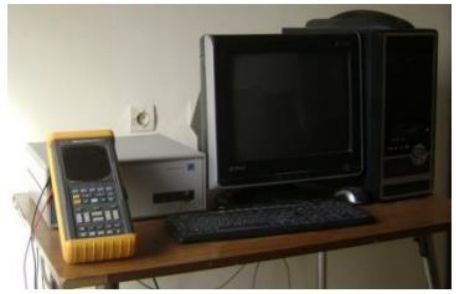

(a)

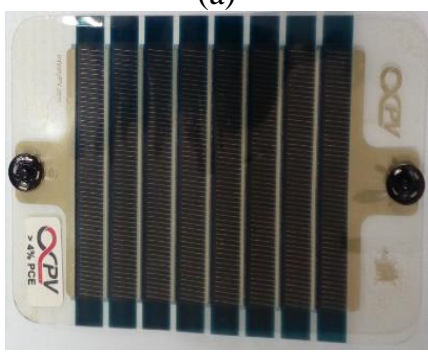

(b)

Figure 3. Experimental platform: a) computer station and MP-160 I-V tracer, b) Organic module

Table 1. Electrical characteristics of the OPV module

\begin{tabular}{cc}
\hline \multicolumn{2}{c}{ Infinity-PV organic module } \\
Surface: $\mathbf{0 . 0 0 8} \mathbf{~ m}^{\mathbf{2}}$ and weight & $\mathbf{0 . 1} \mathbf{k g}$ \\
\hline $\mathrm{P}_{\mathrm{m}}(\mathrm{W})$ & 0.375 \\
$\mathrm{I}_{\mathrm{sc}}(\mathrm{mA})$ & 110 \\
$\mathrm{~V}_{\mathrm{oc}}(\mathrm{V})$ & 6.92 \\
$\mathrm{I}_{\max }(\mathrm{mA})$ & 78 \\
$\mathrm{~V}_{\max }(\mathrm{V})$ & 4.79 \\
$\eta$ (\%) & 4.7 \\
$\mathrm{FF}$ & 0.5 \\
Number of cells in series Ns & 8 \\
\hline
\end{tabular}

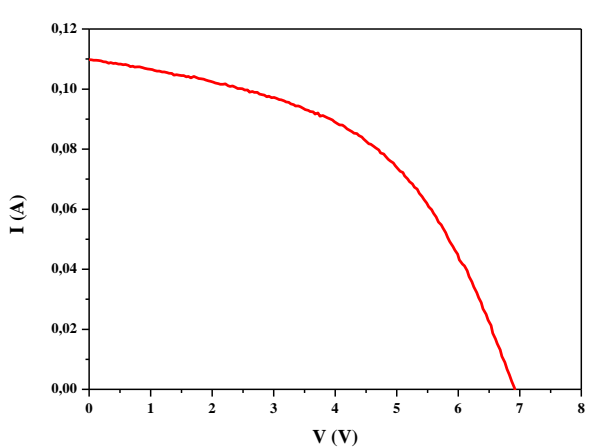

Figure 4. I-V module characteristic in STC

\section{THE ANN APPROACH}

Neural network is specified in finding the appropriate solution for the non-linear and complex systems or the random variable ones. Among its types, there is the back-propagation network, which is more widespread, important and useful. The function and results of the ANN programe are determined by its architecture that has different kinds. The simplest architecture of ANN contains three layers (input layer, hidden layer, and the output layer) [21] Figure 5.

In this technic, can conclude unlimited neural network architectures. The more several hidden layers and neurons in each layer are added to the network; the more complex they become. The realization of the back-propagation network is based on bowth main points (learning and knowledge). This research was utilized by the sigmoid function as an activation 
function to calculate the hidden layer output and the linear function to calculate the output $[8,22]$.

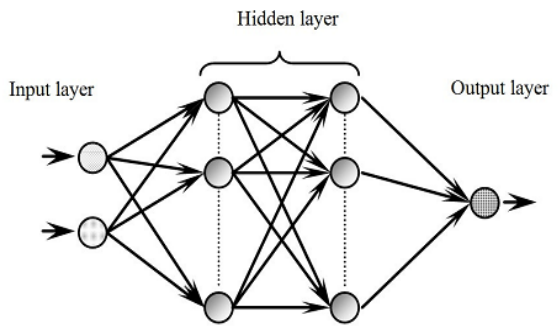

Figure 5. The used neural network

The technic chosen for the modeling of solar cells is the technic of ANN method, which consists of three steps; the choice of neuronal structure, learning and validation. [13, 22]. Table 2. Collected all the used parameters to optimize the ANN model.

The mean quadratic error of our ANN is represented in Figure 6. After 10000 iterations, the ANN mean squared error reaches a very low value $\left(3.9822 \times 10^{-8}\right)$ this proves the reliability of the ANN training.

Table 2. ANN parameters

\begin{tabular}{|c|c|c|c|}
\hline Parameter & \multicolumn{3}{|c|}{ Optimized value } \\
\hline Architecture & \multicolumn{3}{|c|}{ Feed-Forward MLP (Perceptron Multi-Layers) } \\
\hline Hidden Layer & \multicolumn{3}{|c|}{03} \\
\hline $\begin{array}{l}\text { Learning } \\
\text { Rule }\end{array}$ & \multicolumn{3}{|c|}{$\begin{array}{c}\text { Errors Backward propagation (Back } \\
\text { propagation) }\end{array}$} \\
\hline \multirow{6}{*}{$\begin{array}{l}\text { Neurons } \\
\text { layer }\end{array}$} & Input layer & \multicolumn{2}{|c|}{03} \\
\hline & $1^{\text {st }}$ hidden layer & \multicolumn{2}{|c|}{19} \\
\hline & $2^{\text {st }}$ hidden layer & \multicolumn{2}{|c|}{15} \\
\hline & $3^{\text {st }}$ hidden layer & \multicolumn{2}{|c|}{10} \\
\hline & Output Layer & \multicolumn{2}{|c|}{1} \\
\hline & $1^{\text {st }}$ hidden layer & \multicolumn{2}{|c|}{ Logsig } \\
\hline Transfer & $2^{\text {st }}$ hidden layer & \multicolumn{2}{|c|}{ Linear } \\
\hline \multirow[t]{3}{*}{ function } & \multirow{2}{*}{$\begin{array}{l}3^{\text {ird }} \text { hidden layer } \\
\text { Output Layer }\end{array}$} & \multicolumn{2}{|c|}{ Linear } \\
\hline & & \multicolumn{2}{|c|}{ Linear } \\
\hline & $\mathrm{G}\left(\mathrm{W} / \mathrm{m}^{2}\right)$ & $\mathrm{Tc}\left({ }^{\circ} \mathrm{C}\right)$ & $\mathrm{V}(\mathrm{V})$ \\
\hline \multirow[t]{3}{*}{ Entries } & Min & 7.4 & 0 \\
\hline & 1000 & 50.5 & 6.92 \\
\hline & & \multicolumn{2}{|c|}{$\mathrm{I}(\mathrm{mA})$} \\
\hline \multirow[t]{2}{*}{ Output } & Min & \multicolumn{2}{|c|}{$\begin{array}{c}0 \\
110\end{array}$} \\
\hline & Max & & \\
\hline \multirow[t]{2}{*}{$\begin{array}{c}\text { MSE } \\
\text { Learning }\end{array}$} & \multicolumn{3}{|c|}{$4.1093 * 10^{-06}$} \\
\hline & Learning & \multicolumn{2}{|c|}{10750} \\
\hline \multirow[t]{2}{*}{ Data bases } & Validation & \multicolumn{2}{|c|}{3072} \\
\hline & Test & \multicolumn{2}{|c|}{1536} \\
\hline
\end{tabular}

\section{ANN MODEL VALIDATION}

Once MLP (Multilayer Perceptron) is formed, it tends to give graphical responses (curve I-V and P-V in STC) when presented to entries that have never been seen. The objective of this step is ensured that the learning of the neural network is actually reliable and it is able to predict the desired output values for input data not used in learning of the ANN. For this, the output results that obtained by the ANN model must be compared with the experimentally obtained results.

Once the validity of the proposed method for the flexible organic tandem solar cell modules has been verified, we proceed to use this methodology to obtain the $\mathrm{I}-\mathrm{V}$ and $\mathrm{P}-\mathrm{V}$ curves of the OPV module in STC, which is the aim of this article Figure 7.

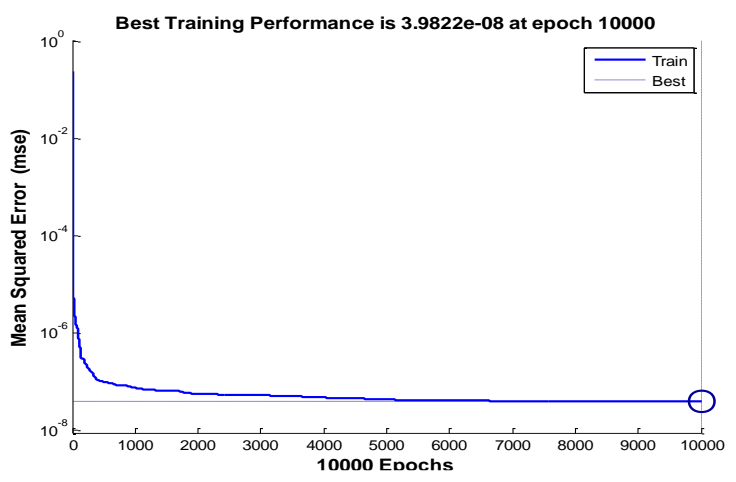

Figure 6. ANN mean quadratic error
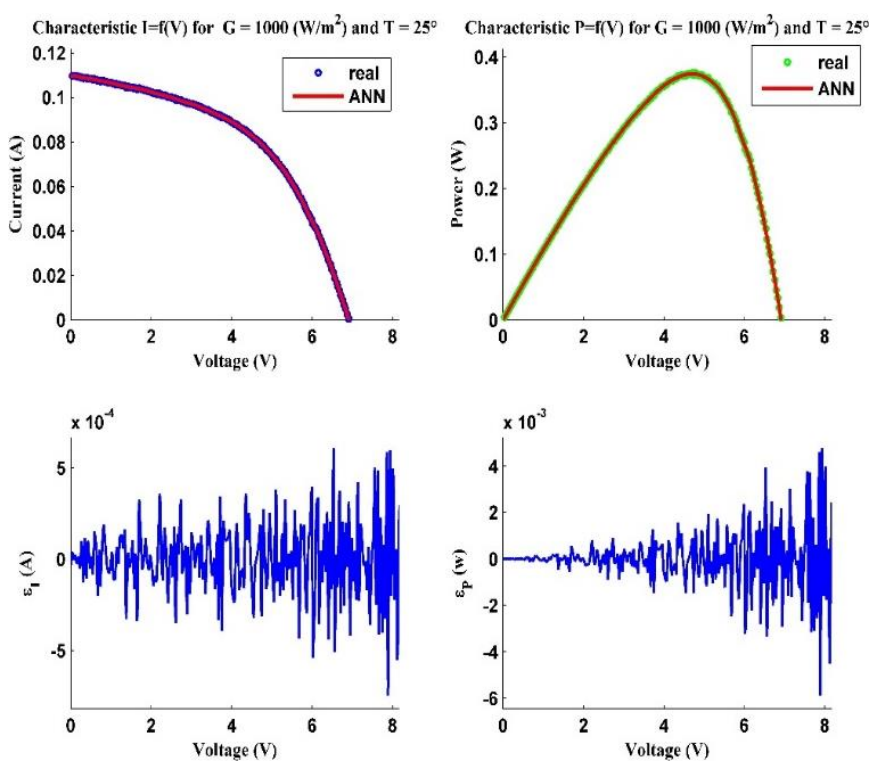

Figure 7. I-V and P-V characteristics of OPV module in STC with error functions

The aforementioned prediction model performances are evaluated in terms of mean absolute percentage error (MAPE), mean bias error (MBE) and root mean square error (RMSE). [23].

The mean absolute error is calculated by the following equation:

$$
M A P E=\frac{1}{N} \sum_{i=1}^{N}\left(\left|\frac{D_{i e}-D_{i m}}{D_{i m}}\right|\right)
$$

The mean absolute error (MAPE) is equal to $0.68 \%$.

The mean bias error (MBE) is calculated by the following equation:

$$
M B E=\sum_{i=1}^{N}\left(\frac{D_{i e}-D_{i m}}{N}\right)
$$

The mean bias error (MBE) is equal to $4.5018 \mathrm{e}^{-09} \mathrm{~A}$

The root means square error (RMSE) is given by the following equation:

$$
R M S E=\sqrt{\sum_{i=1}^{N} \frac{\left(D_{i e}-D_{i m}\right)^{2}}{N}}
$$



A.

The root means square error (RMSE) is equal to $1.8062 \mathrm{e}^{-04}$

Where Die is the estimated value, Dim is the measured value and $N$ is the the number of observations.

The real and simulated curves of the current and power obtained for the studied organic solar module for the day $10 / 05 / 2017$ are shown in the figs. 8 and 9 . Where the day $(10 / 05 / 2017)$ is a normal day with the sun and clouds in the southwest of Algeria (Adrar city). The error between the obtained results (real and simulated of the current and power of the OPV panel) during to the daytime is very acceptable.

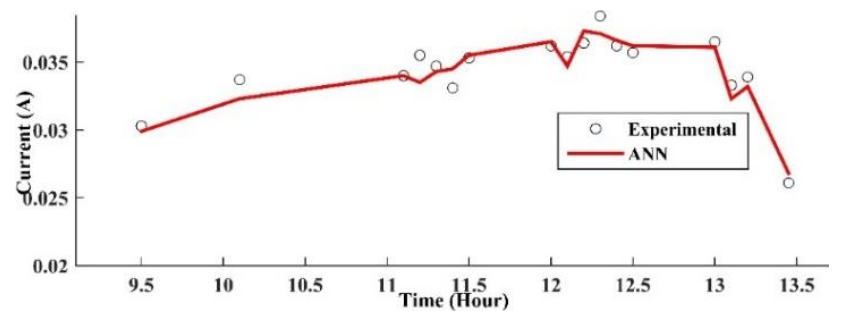

(a)

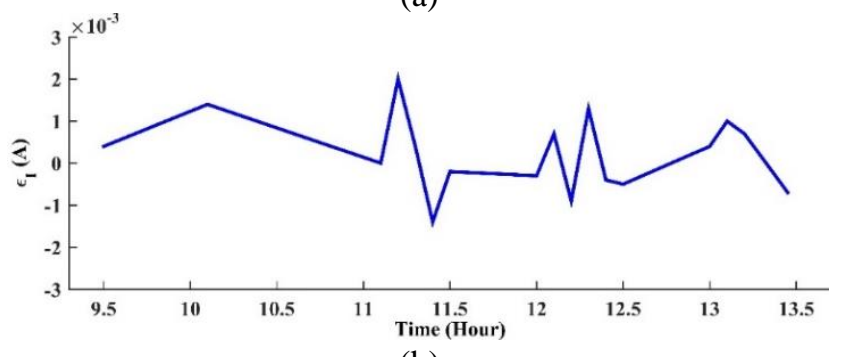

(b)

Figure 8. Current values of the PVO module for the day 10/05/2017. a) Power, b) Error

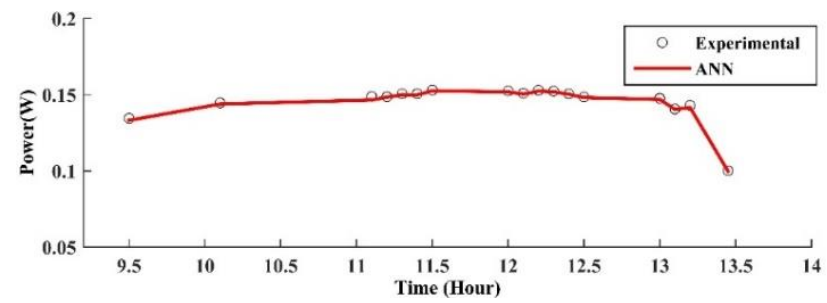

(a)

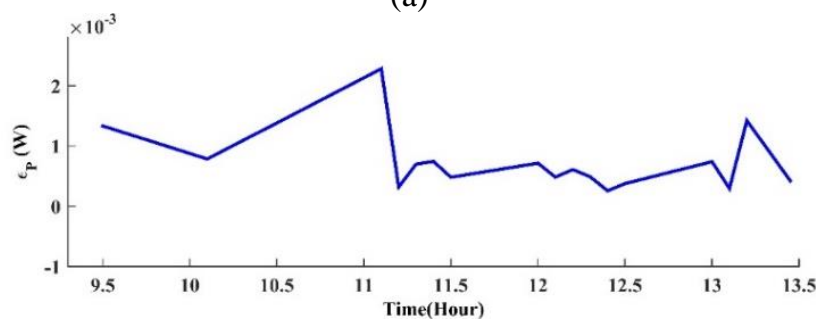

(b)

Figure 9. Power values of the PVO module for the day 10/05/2017. a) Power, b) Error

\section{CONCLUSION}

In this paper, an organic photovoltaic module study is presented. The characterization and modeling results of the electrical current-voltage and power-voltage of the organic photovoltaic (PV) panel are obtained. The electrical parameters of organic flexible tandem solar cell module (current, voltage and power) are characterized and analyzed in the weather condition of southwest Algeria in Adrar city (temperature, irradiation...). A model that present the behavior of the flexible organic tandem solar cell modules under different climatic conditions using the neural networks design is constructed in MATLAB. A good selection of the database is elaborate, the irradiance ranges have been selected from $584 \mathrm{~W} / \mathrm{m}^{2}$ to $1000 \mathrm{~W} / \mathrm{m}^{2}$, the cell temperature varied between 7.4 to $50.5^{\circ} \mathrm{C}$ and the voltage varies from 0 to $\mathrm{V}_{\mathrm{oc}}$. The backpropagation algorithm is used for the ANN training. The obtained results by the simulation of the ANN program showed a good agreement with the results obtained experimentally in the saharan climate (MAPE:0.68 \%, MBE: $4.5018 \mathrm{e}^{-09} \mathrm{~A}$ and RMSE: $\left.1.8062 \mathrm{e}^{-04} \mathrm{~A}\right)$.

\section{REFERENCES}

[1] Gotleyb, D, Sciuto, G.L., Napoli, C., Shikler, R., Tramontana, E., Woźniak, M. (2016). Characterisation and modeling of organic solar cells by using radial basis neural networks. ICAISC 2016, Part I, LNAI 9692: 91103. https://doi.org/10.1007/978-3-319-39378-0-9

[2] Ali, N.C. (2011). Artificial neural network modelling and experimental verification of the operating current of mono-crystalline photovoltaic modules. Solar Energy, 85: 2507-2517.

https://doi.org/10.1016/j.solener.2011.07.009

[3] Moser, F.H., Thomas, A.L. (1963). Phthalocyanine Compounds, Chapman\&Hall, Reinhold New York, London.

[4] Law, K.Y. (1993). Organic photoconductive materials: recent trends and developments. Chemical Reviews 93(1): 449-486. https://doi.org/10.1016/B978012513904-5/50003-X

[5] Elshatter, T.F., Elhagree, M.E., Aboueldahab Elkousry, A.A. (1997). Fuzzy modeling and simulation of photovoltaic system. Proceedings of the 14th European Photovoltaic Solar Energy Conference, https://doi.org/10.1109/PECON.2006.346625

[6] Almonacid, F., Rus, C., Hontoria, L., Fuentes, M., Nofuentes, G. (2010). Characterization of Si-Crystalline PV module by artificial neural networks. A comparative study with other methods. Renewable Energy, 35: 973980. https://doi.org/10.1016/j.renene.2009.11.018

[7] Ceylan, İ., Gedik, E., Erkaymaz, O., Gürel, A.E. (2014). The artificial neural network model to estimate the photovoltaic modul efficiency for all regions of the Turkey. Energy and Buildings, 84: 258-267. https://doi.org/10.1016/j.enbuild.2014.08.003

[8] Yaichi, M., Fellah, M.K., Mammeri, A. (2014). A neural network based mppt technique controller for photovoltaic pumping system. International Journal of Power Electronics and Drive System (IJPEDS), 4(2): 241-255. https://doi.org/10.11591/ijpeds.v4i2.5875

[9] Darwish, A.A.A., Hanafy, T.A., Attia, A.A., Habashy, D.M., El-Bakry, M.Y., El-Nahass, M.M. (2015). Optoelectronic performance and artificial neural networks (ANNs) modeling of $\mathrm{n}-\mathrm{InSe} / \mathrm{p}-\mathrm{Si}$ solar cell. Superlattices and Microstructures, 83: 299-309. https://doi.org/10.1016/j.spmi.2015.03.033

[10] Chan, K.H., Elumalai, N.K., Tayebjee, M.J.Y., Uddin, A., Pillai, S. (2017). Dark carrier dynamics and electrical characteristics of organic solar cells integrated with Ag$\mathrm{SiO}_{2}$ core-shell nanoparticles. Synthetic Metals, 23: 3442. https://doi.org/10.1016/j.synthmet.2016.11.033 
[11] Andersen, T.R., Dam, H.F., Hösel, M., Helgesen, M., Carlé, J.E., Larsen-Olsen, T.T., Suren, G., Andreasen, J,W., Adams, J., Li, N., Machui, F., Spyropoulos, G.D., Ameri, T., Lemaitre, N., Legros, M., Scheel, A., Gaiser, D., Kreul, K., Berny, S., Lozman, O.R., Nordman, S., Välimäki, M., Vilkman, M., Søndergaard, R.R., Jørgensen, M., Brabec, C.J., Krebs, Frederik, C. (2014). Scalable, ambient atmosphere roll-to-roll manufacture of encapsulated large area, flexible organic tandem solar cell modules. Energy and Environmental Science, 7: 2925-2933. https://doi.org/10.1039/c4ee01223b

[12] Luis, M.P., Diego, M., Jesús, P., Daniel, P.A., Dunia, B., Antonio, S. (2017). Analysis of the long-term solar potential for electricity generation in Qatar. Renewable and Sustainable Energy Reviews, 73: 1231-1246. https://doi.org/10.1016/j.rser.2017.01.125

[13] Slimane, L., Khaled, M., Messaoud, H., Youcef, S. (2016). Impedance model for diagnosis of water management in fuel cells using artificial neural networks methodology. Int. J. Hydrogen Energy, 41: 7093-17101. https://doi.org/10.1016/j.ijhydene.2016.07.099

[14] Rashmi, G. (2017). Electrical characterization of a photovoltaic module through artificial neural network: a review. International Journal of Electrical Components and Energy Conversion, 3(1): 14-20. https://doi.org/10.11648/j.ijecec.20170301.12

[15] Ali, N.C. (2011). Artificial neural network modelling and experimental verification of the operating current of mono-crystalline photovoltaic modules. Solar Energy, 85: 2507-2517. https://doi.org/10.1016/j.solener.2011.07.009

[16] Mekki, H., Mellit, A., Salhi, H., Guessoum, A. (2015). Artificial neural network-based modeling and monitoring of photov moritz riede, christian uhrich, ronny timmreck. Johannes Widmer, David Wynands, Marieta Levichkova, 3: 1-9.

[17] Dor, G., Grazia, L.S., Christian, N., Rafi, S., Emiliano, T., Marcin, W. (2016). Characterisation and mo deling of organic solar cells by using radial basis neural networks. (Eds.): ICAISC 2016, Part I, LNAI 9692: 91-103.

[18] Moritz, R., Christian, U., Ronny, T., Johannes, W., David, W, Marieta, L., Mauro, F., Gregor, S., Wolf, G., Martin,
P., Karl, L. (2010). Optimization of organic tandem solar cells based on small molecules. 2010 35th IEEE Photovoltaic Specialists Conference, pp. 20-25. https://doi.org/10.1109/PVSC.2010.5616806

[19] Sadok, M., Benyoucef, B., Benmedjahed, M. (2016). Assessment of $\mathrm{pv}$ modules degradation based on performances and visual inspection in algerian sahara. International Journal Of Renewable Energy Research, 6 (1): 107-116.

[20] Capderou, M. (1985). Atlas Solaire de l'Algérie', Office des Publications Universitaires, Alger 2.

[21] Saadi, A., Moussi, A. (2003). Neural Network Use in the MPPT of Photovoltaic Pumping System, Rev. Energ. Ren. ICPWE 39-45.

[22] Eduard, M. (2000). ANN based peak power tracking for PV supplied dc motors. Solar Energy, 69(4): 343-354. https://doi.org/10.1016/s0038-092x(00)00085-2

[23] Kumar, N., Sharma, S.P., Sinha, U.K., Nayak, Y. (2016). Prediction of solar energy based on intelligent ann modeling. International Journal Of Renewable Energy Research, 6(1): 184-1.

\section{NOMENCLATURE}

$\begin{array}{ll}\text { STC } & \text { Standard Test Conditions } \\ \text { GHI } & \text { Global Horizontal Irradiation } \\ \text { DNI } & \text { Direct Horizontal Irradiation } \\ \text { DHI } & \text { Diffuse Horizontal Irradiation } \\ \text { MSE } & \text { Mean Square Error } \\ \text { MLP } & \text { Multilayer Perceptron } \\ \text { EI } & \text { Current Error }(\mathrm{A}) \\ \text { EP } & \text { Power Error }(\mathrm{W}) \\ \text { FF } & \text { Factor of Form } \\ \eta & \text { photovoltaic conversion efficiency }(\%) \\ \text { Pm } & \text { Maximum power }(\mathrm{W}) \\ \text { T } & \text { Temperature }\left({ }^{\circ} \mathrm{C}\right) \\ \text { TC } & \text { Cell Temperature }\left({ }^{\circ} \mathrm{C}\right) \\ \text { Isc } & \text { Short circuit current }(\mathrm{A}) \\ \text { Voc } & \text { Open circuit voltage }(\mathrm{V}) \\ \text { ANN } & \text { Artificial neural network } \\ \text { G } & \text { illumination }(\mathrm{W} / \mathrm{m} 2)\end{array}$

